\title{
Preliminary analysis of odor legal solutions and study on their implementation possibilities in Poland
}

\author{
Izabela Sówka ${ }^{1 *}$, Leszek Karski ${ }^{2}$ \\ ${ }^{1}$ Wroclaw University of Science and Technology Faculty of Environmental Engineering, Unit of \\ Engineering and Protection of Atmosphere, Wyb. Wyspianskiego 27, 50-370 Wroclaw, Poland \\ ${ }^{2}$ Inspectorate of Environmental Protection, 52/54 Wawelska Str., 00-922 Warsaw, Poland
}

\begin{abstract}
The problem of odor nuisance requires undertaking legal means that aim towards implementation of regulations in order to improve the odor-related quality of air in selected areas in Poland. So far the works carried out in the country were concluded by drawing up 'The guidelines for the bill on counteracting the odor nuisance'. However, as a result of completed social consultations in Poland, the Ministry of Environment, in 2015, resigned from implementing of so called anti-odor act. Currently, the legislature is taking steps which aim at undertaking specific actions in order to introduce solutions, which would directly regulate the issues of odors and the odor nuisance, to the national system. In the countries of the European Union, the issues related to odors are solved in diversified ways and the system still lacks of a uniform proposition, among others related to odor standards. In connection with the above, actions that are taken on a national level should fundamentally aim at developing national odor standards which would take into account the type / the kind of economic activity being a source of odor emission (e.g. clearly separated for existing objects and planned investments), at establishing a procedure and also legal and operational requirements related to determination and the types of zones with defined values of acceptable concentration and determination of reference methodology in monitoring, and modeling the dispersion of odors e.g. including strictly defined frequency of necessary tests. In addition, the process should be accompanied by a creation of financial mechanisms and streams in range of investments related to the development of technology and methods used to limit emission of odors.
\end{abstract}

\section{Introduction}

In the countries of the European Union and generally in the world, the odors, which are the product of direct activity of a man and cause negative effects are commonly classified as contaminants and, throughout the world, are subjected to legal regulations. In such cases the odors are treated as contaminants, which released into the environment may cause a number of negative effects, among others, including: worsening of the quality of the natural environment, damages to property or to the world of plants and life of animals, discomfort;

\footnotetext{
${ }^{*}$ Corresponding author: izabela.sowka@pwr.edu.pl
} 
decrease of the level of safety and quality of life, inability to use the property in a normal way, and disrupting the normal manner of conducting an economic activity [1].

Among the societies which reside in areas exposed to emission of odors, the odors may cause a number of negative reactions, beginning from: anxiety, discomfort, irritation, insomnia, lack of appetite, awkwardness (when visiting guests feel the unpleasant odor), up to specific health effects in forms of: illnesses of the respiratory and digestive systems or skin diseases, and also physical or mental deficiencies [1-2]. Mechanisms related to the reaction of an organism to an odor may include, among others: innate aversion to odors, exacerbation of fundamental conditions related to reception/perception of odor (hypersensitivity), diseases caused by stress or even psychogenic diseases [3].

By taking into account the influence of odors on the mental and emotional sphere, the odor nuisance is defined as a discomfort caused by odor emitting substances or circumstances related to a presence of odors, which may negatively influence a single person or a group of people. It is caused by perception of unwanted odors which result in worsening of the mood [4-5].

Besides olfactory factors, the perception of an odor may be also influenced by external factors, including: situations accompanying the higher concentrations of a odor (housing situation, the length of sleep, tiredness, the length of work in 'odor-accompanied' environment, the condition of the environment and spatial development in an area of odor nuisance presence (current level of odor, social and economic structure in the residential area, architecture) and odor-unrelated properties of the source of pollution (e.g. the level of noise, vibrations, concentration of particulate matter). Those factors - next to the concentration, hedonic quality, intensity and the time of exposure to a specific odor - in a significant way influence the individual perception of emitted odor and definition of the odor as a nuisance. Because of, among others, the complicated nature of perception of a smell and its assessment, the regulations related to odor nuisance in the European Union and throughout the world are solved on a national or a regional level. Mandatory regulations define following elements in various ways: criteria and acceptable values, including, in the scope of: concentration of the odor (expressed in $\mathrm{ou}_{\mathrm{E}} / \mathrm{m}^{3}$ ), reference methods and models and also techniques of control and prevention of odor nuisances [6-8], and the considerations dedicated to odors, covered odor-creating features of gases cover among others: concentration, intensity, character, offensiveness, persistency (CICOP), frequency, intensity, duration, offensiveness and location (so called FIDOL) and hedonic tone $[6,8-10]$.

The presented work aims at an analysis of the solutions used in legal systems of selected European Union countries in relation to issues of assessment of odor nuisances and at indication of initial possibility of their application in Poland, including determination of directions of actions aiming at introduction of complex solutions relating to laws regulating odor issues to the national legal system.

\section{Legal solutions related to the issues of odor nuisance}

Solutions and formal regulations in relation to odors, existing in European systems and throughout the world, have a national or regional range, have no uniform character, are related to various types of odor emission sources and include, among others: Environmental Acts and Regulations, Ambient Air Acts and Regulations, Odor Acts and Regulations, Nuisance Acts and Regulations, Natural Resource Acts and Regulations, Right Farm Acts and Regulations, Agricultural Acts and Regulations, Confined Animal Feeding Operations Acts and Regulations [8-9]. Exception - in a strictly technical aspect (methodological) - is constituted by a specific, commonly applied throughout the world, methodology of odor testing described in the norm: EN 13725:2003 [11], which provides a determined value of 
odor rate emission as a final result (basing on performed measurement of an odor concentration and the knowledge of the stream of tested odor emitting gases). It is a value, which may be applied to assess and verify the odor level, in relation to, used in specific regulations, criteria concerned with the issues of odor nuisance, including the value of odor emission rate/factor (ou $/ \mathrm{E}$, Figure 1) and (imission) odor concentration ( $\mathrm{ou}_{\mathrm{E}} / \mathrm{m}^{3}$, Figure 2). The review of implemented in European legal systems criteria in relation to assessment of odor influence (assessment of odor nuisance) of chosen sources of odor emission done by [6] indicates that mainly - in operational range - the established criteria include issues related to standards corresponding to the value of odor concentration or to a concentration of single odor emitting substance described by usage of reference tools and methods (measurement methods - including dynamic olfactometry in the standard mentioned above, calculation methods - reference models) in a point of emission (so called maximum emission standard) or in the receptor points (so called maximum impact standard), and in selected scenarios of solutions, in specific distances from tested source (separation distance standard). In addition, in chosen legal systems, there is a specific, relating to the number of odor complaints or annoyance level, standard called maximum annoyance standard, and in the scope of technological solutions in accordance with those recommended in BAT, among others, techniques of odor emission limiting (odor nuisance) - we may consider so called technology standard [6]. Mentioned reference measurement and calculation methods (described by standards) are applied most of all in order to determine the value of emission, and then, the odor concentration in receptor points, in relation to, already described in the legal regulations of specific countries, odor imission limits, including related to jurisdictional mission standard called odor impact criteria (OIC) which embraces the value of odor concentration, the percentile value and the time of averaging, which may be calculated, for example, in dependence of the type and the nature of conducted economic activity (Figure 1-2). According to currently possessed knowledge applying such kind of solution is dominating among 28 countries subjected to analysis, which in their legal systems have regulations related to odors [6].

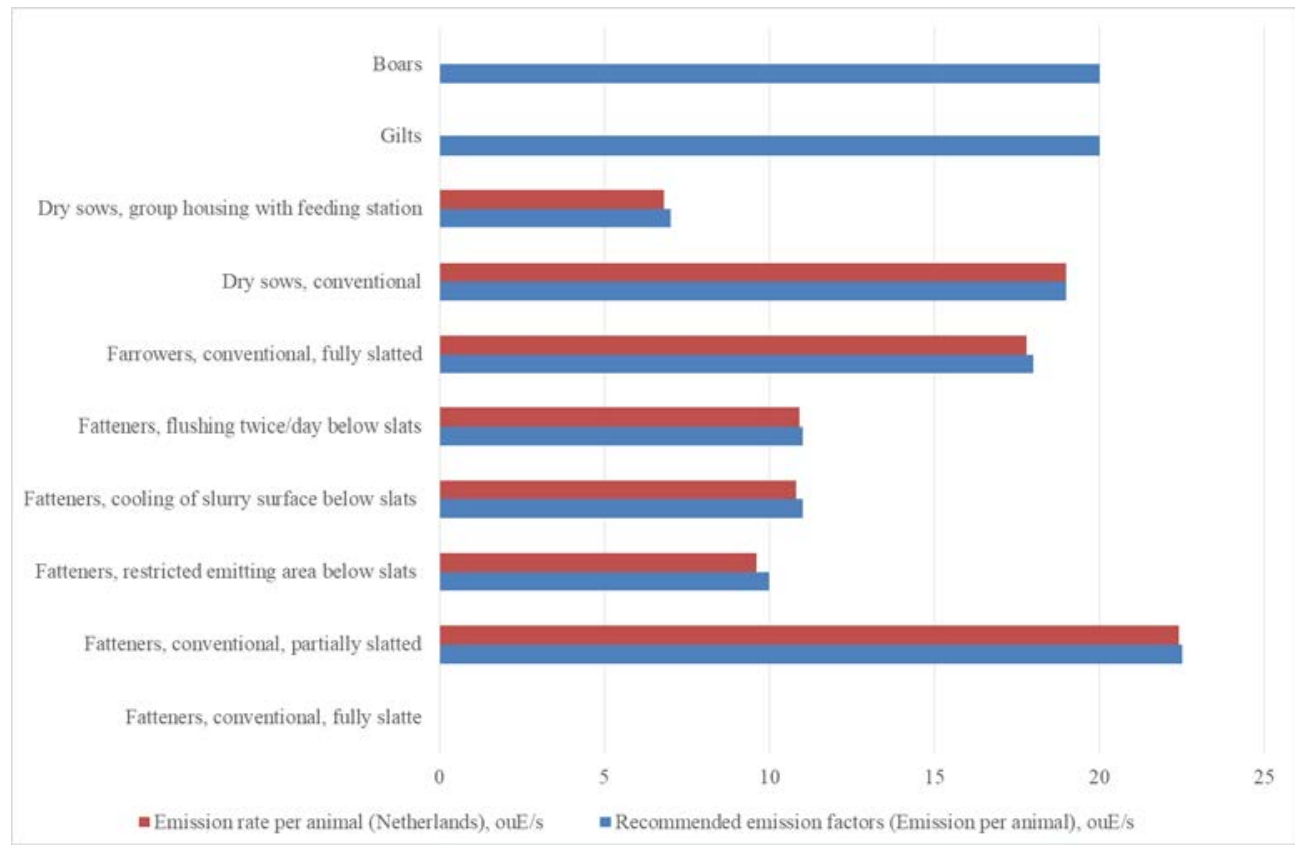


Figure 1. Examples of (odor) emission factors $\left(\mathrm{ou}_{\mathrm{E}} / \mathrm{s}\right)$ for pigs at different stages in the life cycle (based on data published by [12]).

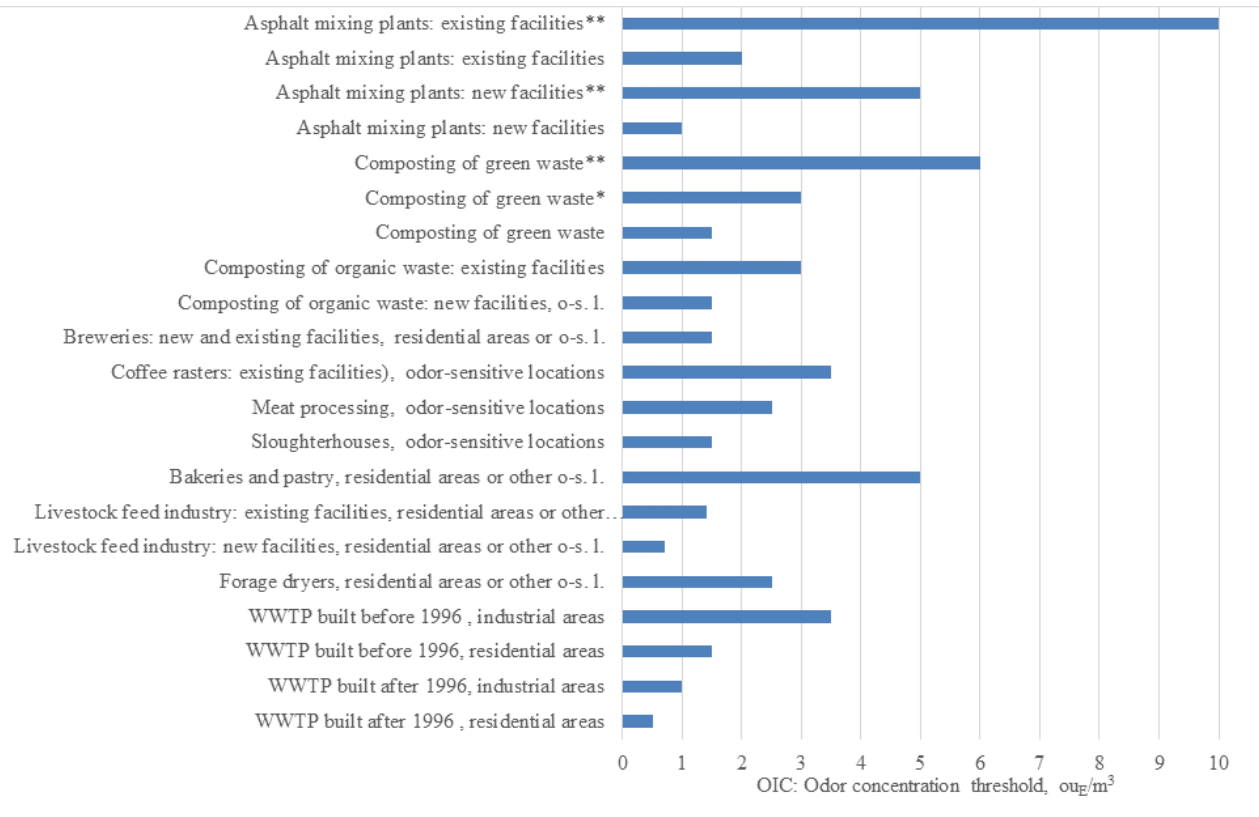

Figure 2. Examples of selected maximum (odor) impact standards $\left(\mathrm{ou}_{\mathrm{E}} / \mathrm{m}^{3}\right)$ in Netherlands for values of percentile $\mathrm{P}=98$ and average time $\mathrm{A}_{\mathrm{t}}=1 \mathrm{~h}$ with exception: * $\mathrm{P}=99,5 \mathrm{At}=1 \mathrm{~h} ; * * \mathrm{P}=99,9$ At $=1 \mathrm{~h}$; o-s. 1: odor sensitive locations (based on data published by [6]).

Another issue in the context of odor-active substances is, therefore, an analysis of implemented solutions in range of measurement methods (for instance, mentioned method of dynamic olfactometry) and mathematical modeling of odor propagation, which include advanced tools - models of odor dispersion in the atmosphere - used to estimate odor concentration in receptor points with a developed meteorological module (preprocessor).

\section{Indicating the line for action in relation to a possibility of creating new provisions on a national level}

The activities aiming at establishment of laws, undertaken in Poland so far, in relation to odor nuisance, were concluded with drawing up of 'The guidelines for the bill on counteracting the odor nuisance' from 22 December 2010, which were subjected to social consultation. As a result of the consultations the Ministry of Environment, in 2015, resigned from implementing, so called, anti-odor act [13]. Despite the previous ministerial actions, as a result of which there were created, among others, legal regulations corresponding to the issue of odors (table 1) and 'The code of counteracting odor nuisance' that was developed in 2016 [14] there is clearly a need - bodies of Environmental Protection Inspection in 2016 have processed over 1 thousand of complaints, which were related to odor nuisance [15] - to draw up legal regulations on a national level, related to the odor nuisance.

Table 1. Examples of laws corresponding to the issue of odor in Poland (based on [7]).

Provision

Content of the article 
Civil Code Act from 23 April 1964. (Journal of Laws, 2017, item 459, as amended)
Environmental Protection Act, 27 April 2001 (Journal of Laws, 2016, item 672)
- Art. 144 'The owner of the property, while exercising his rights, shall refrain from activities, which would disturb a usage of neighboring properties in an excessive manner, other than that which results from social and economic designation of the property and local conditions.' [16]

- Art. 362 sec. 1. 'If an entity which benefits from the environment, influences this environment in a negative way, the environmental protection body has a right to, through the means of a decision, impose an obligation of :

1) limiting the influence on the environment, and its endangerment;

2) restoring the environment to a proper condition.

sec. 2. In the decision, identified in the sec. 1, the environmental body may set out:

1) the scope of limitation of the influence on the environment, and condition to which the environment shall be restored;

1a) activities aiming at limiting the influence on the environment or at restoring the environment to a proper condition;

- Art. 363. 'A head of the commune, a mayor or a president of the city may, through the means of a decision, impose on an individual, whose actions influence the environment negatively, an obligation to undertake activities, in a specified period of time, which aim at

1) limiting the negative influence on the environment and its endangerment;

2) restoring the environment to a proper condition.' [17]

-Art. 63. sec. 1. 'Obligation to complete an assessment of the influence of an endeavor on the environment, for planned endeavor which may potentially influence the environment in a significant way, may be imposed by, through the means of a resolution, an

The Act on Provision of Information on the Environment and its Protection, Public Participation in Environmental Protection and Environmental Impact Assessment (Journal of Laws, 2016, item 353).

The Act on fertilizers and fertilizing from 10 July 2007 (Journal of Laws, 2015, item 625, as amended) authority which is competent to issue a decision on environmental constraints, taking into account, in total, flowing criteria:

1) kind and nature of the endeavor, including: (...)

d) emission and presence of any other nuisances,...

-Art. 97. sec.1. 'Regional Director of Environmental Protection, through the means of a resolution, may impose an obligation to complete an assessment of the influence of an endeavor on the area of Natura 2000 (Nature 2000), by taking into account following constraints:

1) kind and characteristics of an endeavor, which include (..): d) emission and presence of any other nuisances.' [18]

Art. 23. sec. 2. 'Fertilizers, including ones marked as 'EC Fertilizer', and substances enhancing the cultivation of plants in a liquid form, shall be transported in closed and sealed packages, containers or tanks.'

-Art. 25. sec. 1 Unfermented and fermented liquid manure shall be stored only in sealed containers with a volume which makes it possible to cumulate at least 4-month production of this fertilizer. These containers should be closed, in understanding of provisions based on the art.7, sec. 2, point 2 of the Act from 7 July 1994 [19] related to location and technical conditions which shall be met by agricultural buildings.' [20]

-Art. 16 sets out that the waste management may not cause, among others, nuisances caused by an odor or a noise.

-Art. $160 \mathrm{sec}$. 1. 'Administrator of a waste incineration plant or coincineration plant is obliged to take necessary precautions, during receipt and thermal transformation of waste, to take necessary precautions which aim at prevention or limitation of a negative influence on the environment, especially in relation to the 


\begin{tabular}{|c|c|}
\hline & $\begin{array}{l}\text { contamination of air, soil, surface and ground waters, odors and } \\
\text { noise, and also a direct threat to a human life or health, and to } \\
\text { comply with the requirements in scope of thermal transformation of } \\
\text { waste. '[21] }\end{array}$ \\
\hline $\begin{array}{l}\text { Regulation of the Minister } \\
\text { of Agriculture and Food } \\
\text { Economy on location and } \\
\text { technical conditions which } \\
\text { should be met by } \\
\text { agricultural buildings, } \\
\text { from } 7 \text { October 1997 } \\
\text { (Journal of Laws, 2014, } \\
\text { no.0, item 81, as } \\
\text { amended) }\end{array}$ & $\begin{array}{l}\text {-Art. 12. 'Agricultural buildings which cause a nuisance in their } \\
\text { surroundings, especially including pollination, odors or release of } \\
\text { toxic substances, shall be isolated from adjacent areas with a green } \\
\text { strip composed of high and average-height growing plants.' } \\
\text { - Art. } 46 \text {. 'The agricultural buildings, inside which there are released } \\
\text { substances and odors, which are harmful to health, shall be equipped } \\
\text { with efficient ventilation system, during the temporary presence of } \\
\text { the staff, which provides that activities related to cleaning, repair and } \\
\text { conservation, are performed in a manner which is in accordance with } \\
\text { appropriate regulations related to occupational health and safety'. } \\
\text { [22] }\end{array}$ \\
\hline $\begin{array}{l}\text { Regulation of the Minister } \\
\text { of Infrastructure on } \\
\text { location and technical } \\
\text { conditions, which should } \\
\text { be met by buildings, from } \\
12 \text { April } 2002 \text { (Journal of } \\
\text { Laws, 2015, no.0, item } \\
\text { 1422) }\end{array}$ & $\begin{array}{l}\text {-Art. } 12 \text { sec. 6. 'Livestock or industrial building, by taking into } \\
\text { account separate regulations and ones contained within } \S 13,60 \text { and } \\
271-273 \text {, may not be situated in a way, in which the wall with } \\
\text { window openings or door openings is in a distance lower than } 8 \mathrm{~m} \text {, } \\
\text { from a wall of existing specific buildings located on a construction } \\
\text { plot. These buildings include: residential buildings, collective } \\
\text { residential buildings or public utility buildings or a building for } \\
\text { which there is a final decision about a permit for its construction, } \\
\text { subject to sec. } 3 \text {, point } 4 \text {.' [23] }\end{array}$ \\
\hline $\begin{array}{l}\text { Regulation of the Minister } \\
\text { of Economy on technical } \\
\text { conditions which should } \\
\text { be met by liquid fuel } \\
\text { depots and stations, long- } \\
\text { distance transmission } \\
\text { pipelines used to transmit } \\
\text { crude oil and oil products, } \\
\text { and their location, from } 21 \\
\text { November } 2005 \text { (Journal } \\
\text { of Laws, } 2014 \text {, no.0, item } \\
1853 \text { ) }\end{array}$ & $\begin{array}{l}\text { - Art. 6. sec.1 'Containers designated to store crude oil and oil } \\
\text { products and also long-distance transmission pipelines and } \\
\text { technological pipelines shall be subjected to technical evaluation and } \\
\text { leakage tests, provided that separate regulations do not state } \\
\text { otherwise.' [24] }\end{array}$ \\
\hline $\begin{array}{l}\text { Ordinance of the Minister } \\
\text { of the Environment on } \\
\text { reference values for } \\
\text { specific substances in the } \\
\text { air, from } 26 \text { January } 2010 \\
\text { (Journal of Laws, 2010, } \\
\text { no.16, item 87) }\end{array}$ & $\begin{array}{l}\text { The ordinance sets out determined reference values for some of the } \\
\text { substances in the air, in relation to the health protection. Among } 167 \\
\text { substances, there were determined also odor-active substances [25]. }\end{array}$ \\
\hline $\begin{array}{l}\text { Regulation of the Minister } \\
\text { of the Environment, from } \\
30 \text { April 2013, on landfill } \\
\text { sites (Journal of Laws, } \\
2013 \text {, item 523) }\end{array}$ & $\begin{array}{l}\text {-Art. } 10 \text { sec. } 1 \text { 'Landfill site shall be surrounded by a green strip } \\
\text { composed of trees and shrubs, in order to limit to a minimum, the } \\
\text { inconveniences and threats caused by waste located in the landfill } \\
\text { site formed as a result of odor and particulate matter emission, } \\
\text { carrying the waste by the wind, noise and road traffic, influence of } \\
\text { animals, formation of aerosols and outbreaks of fire.' [26] }\end{array}$ \\
\hline
\end{tabular}

Analysis of the regulations on an European level clearly indicates, that evaluation of odor nuisance (treated as a phenomenon) should be done by measuring odor concentration in receptor points $\left(\mathrm{ou}_{\mathrm{E}} / \mathrm{m}^{3}\right)$ - for instance, basing on the emission value determined at the 'source' and analyses with usage of model tests - because considering only one primary compound (and its concentration) as a cause of nuisance in a selected problematic area may be fundamentally inefficient (odors are defined as a mixture of even hundreds of substances 
[27-29] especially in case of areas, where a very high number of complaints and protests of local social communities is registered as a result of poor / progressively worsening odorquality of the air. In Poland, provisions regulating issue of odors in a direct way (e.g. odor standards, measurement and calculation reference methods), would have a relevant utilitarian meaning, especially when considering the high number of registered complaints and court proceedings taking place on a national level. In order to do that it is necessary to undertake actions which include among others: defining odor/odorants as a pollution of the air, establishing national odor standards (e.g. in relation to odor concentration) which take into account a type / kind of economic activity and a nature / kind of installation being a source of odor emission, which would be clearly separated for existing objects and planned investments, developing the procedure, legal and operational requirements related to determination and kinds of zones with defined values of permitted concentration, measurement / assessment of efficiency of deodorization installation and investment project 'acceptance' in this scope - in case of a necessity of its presence, development of complaint system and procedure of complaint analysis, creating market possibilities in order to establish a network of laboratories - accredited entities - in scope of performing e.g. emission measurements (necessity to indicate the measurement output in accordance with the reference methodology in odor monitoring, together with a strictly defined frequency of required tests).

\section{Summary}

Europe lacks of a uniform for every country of EU, regulations in relation to odors. Legal solutions available throughout the world include as well regulations in the scope of emission standards, acceptable levels, as in the scope of test methods and modeling of odor propagation, and also the assessment of their nuisance level, among others, with usage of sociological survey. In Polish conditions, an issue of a high importance, would be capturing in possible regulations, next to odor standards (emission and imission) - which would also include hedonic quality of odor, or a kind of conducted activity - zones around construction objects which cause an odor nuisance.

Evolution of regulations in relation to odors in Poland, should be supported by creation of mechanisms and financial streams in scope of investments related to development of technology and methods used to limit the emission of odors.

This work was supported by a statutory research No. 0401/0065/16.

\section{References}

1. J. Nicell , Atmos. Environ. 43, 196-206 (2009)

2. A. Jaremków, Ł. Szałata, B. Kołwzan, I. Sówka, J. Zwoździak, K. Pawlas, Polish Journal of Environmental Studies 26, 127-136 (2017)

3. D. Shusterman, Arch. of Environ. Health 47, 76-87 (1992)

4. VDI 3883, part I Effects and assessment of odours. Psychometric assessment of odour annoyance. Questionnaires (Beuth Verlag, Berlin, 1997).

5. E. Vance, Nature 455, 726-728, (2008)

6. M. Brancher, K. D. Griffiths, D. Franco, H. de Melo Lisboa, Chemosphere 168, 1531$1570(2017)$

7. I. Sówka, A. Bokowa, Ł. Pachurka, A. Grzelka., Przegląd Komunalny 4, 15-18 (2017) (in Polish) 
8. L.Woźniak, Legal regulations on counteracting odor nuisances in selected countries of the European Union together with the commentary about social and economic consequences of their implementation, Analyses and Topical Papers Unit of the Analyses and Documentation Office, Copyright by Chancellery of the Senate (2014) (in Polish)

9. A. H. Bokowa, Chemical Engineering Transactions 23, 32-36 (2010)

10. M. Górski, Przegląd Komunalny 4, 16-17 (2016) (in Polish)

11. EN 13725:2003, Air Quality. Determination of Odour Concentration by Dynamic Olfactometry

12. M. Górski, Przegląd Komunalny 2, 20-21 (2017) (in Polish)

13. EPA: Odour Impacts and Odour Emission Control Measures for Intensive Agriculture. Final report, (R\&D Reports Series No 14, 2001)

14. The code of counteracting odor nuisance (Department of Air and Climate Protection, Polish Ministry of the Environment, Warsaw, September 2016)

15. http://www.gios.gov.pl/pl/aktualnosci/448-odory-a-zakres-dzialan-inspekcji-ochronysrodowiska (access: 11.11.2017)

16. Civil Code Act from 23 April 1964. (Polish Journal of Laws, 2017, item 459, as amended)

17. Environmental Protection Act from 27 April 2001 (Polish Journal of Laws, 2016, item 672)

18. The Act on Provision of Information on the Environment and its Protection, Public Participation in Environmental Protection and Environmental Impact Assessment (Polish Journal of Laws, 2016, item 353)

19. Construction Act (Polish Journal of Laws, 2013, item 1409, as amended 1)

20. The Act on fertilizers and fertilizing from 10 July 2007 (Polish Journal of Laws, 2015, item 625 , as amended)

21. Waste management act from 14 December 2012 (Polish Journal of Laws, 2013, item 21 , as amended)

22. Regulation of the Minister of Agriculture and Food Economy on location and technical conditions which should be met by agricultural buildings from 7 October 1997 (Polish Journal of Laws, 2014, no.0, item 81, as amended)

23. Regulation of the Minister of Infrastructure on location and technical conditions, which should be met by buildings from 12 April 2002 (Polish Journal of Laws, 2015, no.0, item 1422)

24. Regulation of the Minister of Economy on technical conditions which should be met by liquid fuel depots and stations, long-distance transmission pipelines used to transmit crude oil and oil products, and their location from 21 November 2005 (Polish Journal of Laws, 2014, no.0, item 1853)

25. Ordinance of the Minister of the Environment on reference values for specific substances in the air from 26 January 2010 (Polish Journal of Laws, 2010, no.16, item 87)

26. Regulation of the Minister of the Environment from 30 April 2013, on landfill sites (Polish Journal of Laws, 2013, item 523)

27. N. Hudson, G.A. Ayoko, Bioresource Technology 99, 3982-3992 (2014)

28. M. Brattoli, G. De Gennaro, V. De Pinto, L.A. Demarinis, S. Lovascio, M. Penza, Sensors 11, 5290-5322 (2011)

29. P. Gostelow, S. Parsons, R. Stuetz, Water Research 35, 579-597 (2001) 